\title{
Preliminary Morpho-Mechanical Investigation of X7475 Al-Alloys Produced from Recycled Beverage Can
}

\author{
Abubakar Kazeem ${ }^{1,2}$, Mohammed H. Rady², Amkpa Job Ajala ${ }^{3}$, Nur Azam Badarulzaman ${ }^{2, *}$, \\ Wan Fahmin Faiz Wan Ali ${ }^{4}$ \\ ${ }^{1}$ Department of Science Policy and Innovation Studies, National Centre for Technology Management (NACETEM), Nigeria \\ ${ }^{2}$ Faculty of Mechanical and Manufacturing Engineering, Universiti Tun Hussein Onn Malaysia (UTHM), Malaysia \\ ${ }^{3}$ Department of Foundry Engineering, Federal Polytechnic, Idah, Nigeria \\ ${ }^{4}$ Faculty of Mechanical Engineering, Universiti Teknologi Malaysia (UTM), Malaysia
}

Received August 1, 2019; Revised September 28, 2019; Accepted December 15, 2019

Copyright $\bigcirc 2019$ by authors, all rights reserved. Authors agree that this article remains permanently open access under the terms of the Creative Commons Attribution License 4.0 International License

\begin{abstract}
The need to turn around the beverage can recycle table from conventional can-can to can-automobile (bumper applications) that was seen as a gap to be filled through a novel Experimental 7475 Aluminium Alloy (X7475). In this study, Aluminium, Zinc, Manganese and Copper were sourced from Recycled Beverage Can (RBC), spent DR 20-BG/T 8897.2 - 2008 Hawk battery and coils of used standing fans respectively. Experimental samples were stir cast. Morphological investigations on over 35 sites revealed elemental composition, nature of defects and possible phases. Annealed (O), naturally aged (T4) and artificial aged (T6) samples were indented for hardness $(\mathrm{H})$. Imperfections and inclusions such as $\mathrm{C}, \mathrm{O}$ (pores), $\mathrm{Na}$ and $\mathrm{Fe}$ were observed in the $\alpha$-Al phase. Hardening precipitates like $\mathrm{MgZn}_{2}, \mathrm{Mg}_{3} \mathrm{Zn}_{3} \mathrm{Al}_{2}, \mathrm{Mg}_{32}\left(\mathrm{Zn}, \mathrm{Al}_{49}\right.$ and $\mathrm{Al}_{0.5} \mathrm{Fe}_{3} \mathrm{Si}_{0.5}$ were identified. Peak obtainable $\mathrm{H}$ of $140.45 \mathrm{Hv}$ (T6), 134.32 Hv (T4) and $89.11 \mathrm{Hv}(\mathrm{O})$ with the least $\mathrm{H}$ of 52.18 Hv. Pores and casting defects were observed due to the production route and constituents from secondary sources which affected the mechanical properties. Future research should focus on Optimization of Mechanical Properties. H should be correlated with tensile strength. The use of alumina crucibles may be options.
\end{abstract}

Keywords Morpho-Physical, Recycled Beverage Can, X7475 Al-Alloy, Phases, Defects

\section{Introduction}

The quest for saving in fuel consumption, weight, customer-driven innovations, environmental and industrial regulations in the automobile industry has spurred an opportunity for the aluminium recycling industry. These are drivers of changing the Can-Can paradigm to Canautomobile applications. This initiative supports the target of magnifying the quantity of aluminium in the automobile industry by 2025 [1]. One of such areas of application is in the beam of the bumper [2-4].

The X7475 is a novel alloy cast from RBCs. This alloy has the potentials of being used for production of beam of automobile bumper.

Defects like volumetric shrinkage occurred during solidification within a range from 3.5 to $8.5 \%$. Pores and shrinkage porosity were formed [3]. These imperfections affect the mechanical, physical, microstructure and morphology of the material in addition to HTs, alloy composition and production route.

Morpho-mechanical characterizations are also affected by the cooling rate during and after solidification. For instance, hydrogen porosity, misruns, cracks, moisture reactions, folds, and tears are inevitable macro and micro structural defects that strongly influence mechanical and fatigue performance [6].

The literature falls short in characterizing the $7 \mathrm{xxx}$ aluminium alloy produced from RBCs. The characterizations in George \& Knutsen [7] concentrated on a commercial AA7075 and custom-made A713 alloy. The study concluded using only 3 spectra for the investigation. Jiang, et al [8] investigated the coarsening and microstructural evolution of 7005 aluminium alloy in as-received and T6 condition. Shrinkage, pores and precipitates in $\mathrm{Al}-\mathrm{Cu}, \mathrm{Al}-\mathrm{Mg}-\mathrm{Cu}, \mathrm{Al}-\mathrm{Mg}-\mathrm{Zn}$ and $\mathrm{Al}-\mathrm{Mg}-\mathrm{Si}$ alloys were investigated in the study conducted by Sigmund et al [9], but not the Al-Zn-Mg-Cu alloy produced using $80 \%$ recycled constituents. In the presence of $\mathrm{Zn}, \mathrm{Mg}, \mathrm{Mn}, \mathrm{Cu}$, and $\mathrm{Al}$ expected phases including $\mathrm{Al}_{6} \mathrm{CuMg}_{4}, \mathrm{Al}_{2} \mathrm{Mg}_{3} \mathrm{Zn}_{3}, \mathrm{AlCuMg}, \mathrm{Al}_{2} \mathrm{Cu}$ and $\mathrm{MgZn}_{2}$ [9] however, defects may affect the phase formations. 
The aim of this paper was to characterize defects and imperfections in form of pores and volume shrinkage of the novel X7475 stir cast alloy. The morphology was correlated with $\mathrm{H}$ after HTs.

\section{Materials and Methods}

Ingots of $\mathrm{Al}, \mathrm{Zn}$ and $70 \% \mathrm{Cu}-30 \% \mathrm{Al}$ were cast using a gas fired melting furnace and $2 \mathrm{Kg}$ capacity induction furnace of JT0332 model respectively. Al was recovered from RBCs while Zn was obtained from DR 20 standard, BG/T 8897.2 - 2008 Hawk battery. Cu was from the coils of used standing fans of 2-ARI 410 standard.

Percentage weight (wt. \%) measurement was done on Mettler Toledo Model PL 303 digital weighing machine. Wt. \% of Zn varied from 5.0-4.0, Mg was 1.50-1.00 and 0.075-0.025 was for Mn. Improvised stainless steel crucible was used in induction furnace. $\mathrm{Al}, \mathrm{Zn}, 70 \%$ $\mathrm{Cu}-30 \% \mathrm{Al}, \mathrm{Mn}$ and $\mathrm{Mg}$ were charged in that order. Manual stirring was adopted and pouring into a tailor-made permanent steel mould that was done with a distance of 45 $\pm 10 \mathrm{~cm}$ maintained between the furnace and mould, and pouring temperature was $720-730{ }^{\circ} \mathrm{C}$.

Alloys were taken through heat treatments (HT) using the Carbolite HTF 1800 box furnace in accordance with AMS 2771. Samples were placed on alumina plate to avoid contamination and abrasion. Coupons were sectioned and prepared for investigation using silicon carbide papers of 400, 600 and 800 grits. Mounting on sample holder for EDX was according to the limit of $13 \mathrm{~mm}$ height. Morphological characterization (SEM/EDX) was done at different magnifications focusing on over 50 sites of interest, using the made in USA Hitachi VP-SEM, SU1510 technology set at $15.0 \mathrm{kV}$. The characterization was informed by the peculiarity of the shrinkage pores, gas bubbles, inclusions of foreign matter and cracks [10].

$\mathrm{H}$ test preparation was per modified ASTM E384-17, test per ASTM E18. MicroH (MH) analysis was done on a Shimadzu HMV-2, C227-E013, Vickers MH Tester. Load, duration and points of test were set at $490.3 \mathrm{mN}(0.05 \mathrm{Hv})$, 10 sec and 9 respectively.

\section{Results and Discussion}

The elemental analysis in Figure $1 \mathrm{a}$ and $\mathrm{b}$ revealed the presence of $\mathrm{Al}, \mathrm{Zn}, \mathrm{Mg}, \mathrm{Mn}, \mathrm{Fe}, \mathrm{Si}, \mathrm{Cu}$ and $\mathrm{O}$ which supported the growth of precipitates, hardening phases and dendrite growth like $\mathrm{MgZn}_{2}, \mathrm{Al}_{4} \mathrm{C}_{3}, \mathrm{Mg}_{5} \mathrm{Al}_{8}$ due to $\mathrm{HT}$ and production route.

Figure 2, analysis of dislocation sites, is a conglomeration of boundaries supporting the formation of dislocation walls and hardening phases like $\operatorname{MgZn}_{2}$ that produce plastic deformation. Materials handling route was responsible for the discrepancies observed between calculated and experimental wt. \% [11].

Interdendritic separation as in Figure 2 supported the pore formation due to liquid network fragmentation. HT supported the formation of phases and reduced pockets immobilized by surface tension during solidification [3].

Analysis of 3 flash points (figure $3 \mathrm{a}-\mathrm{d}$ ) revealed that the AC alloy was inhomogeneous as elemental scanning differs from boundaries to matrix. This supported the study of Olawale et al [12] on permeability of the solid system. 

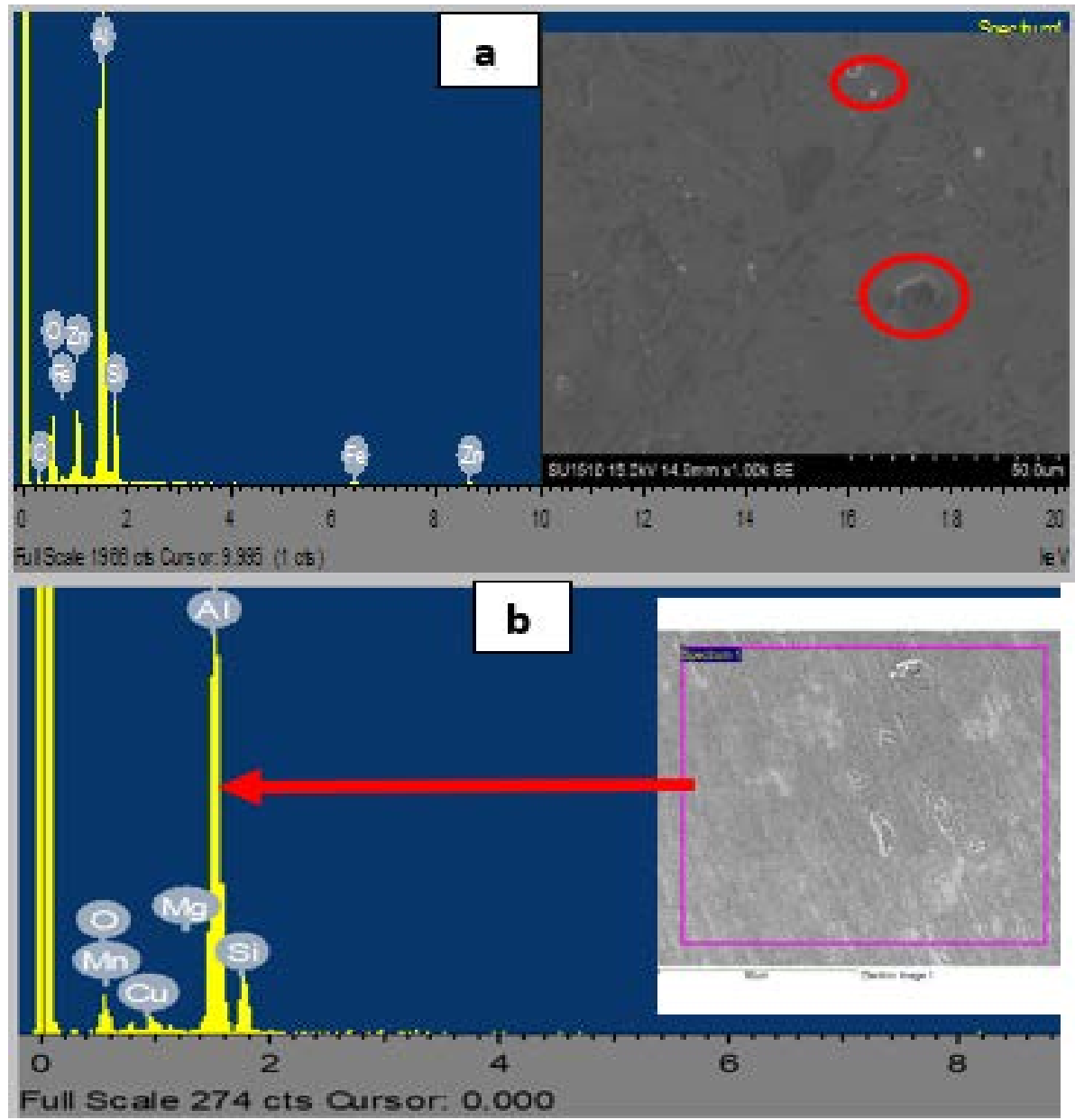

Figure 1. Morphology and Element Analysis of Al-Zn-Mg-Mn alloy (a) SEM of 5 wt \% Zn polished with pores in red (b) Spectrum and Elemental Analysis.

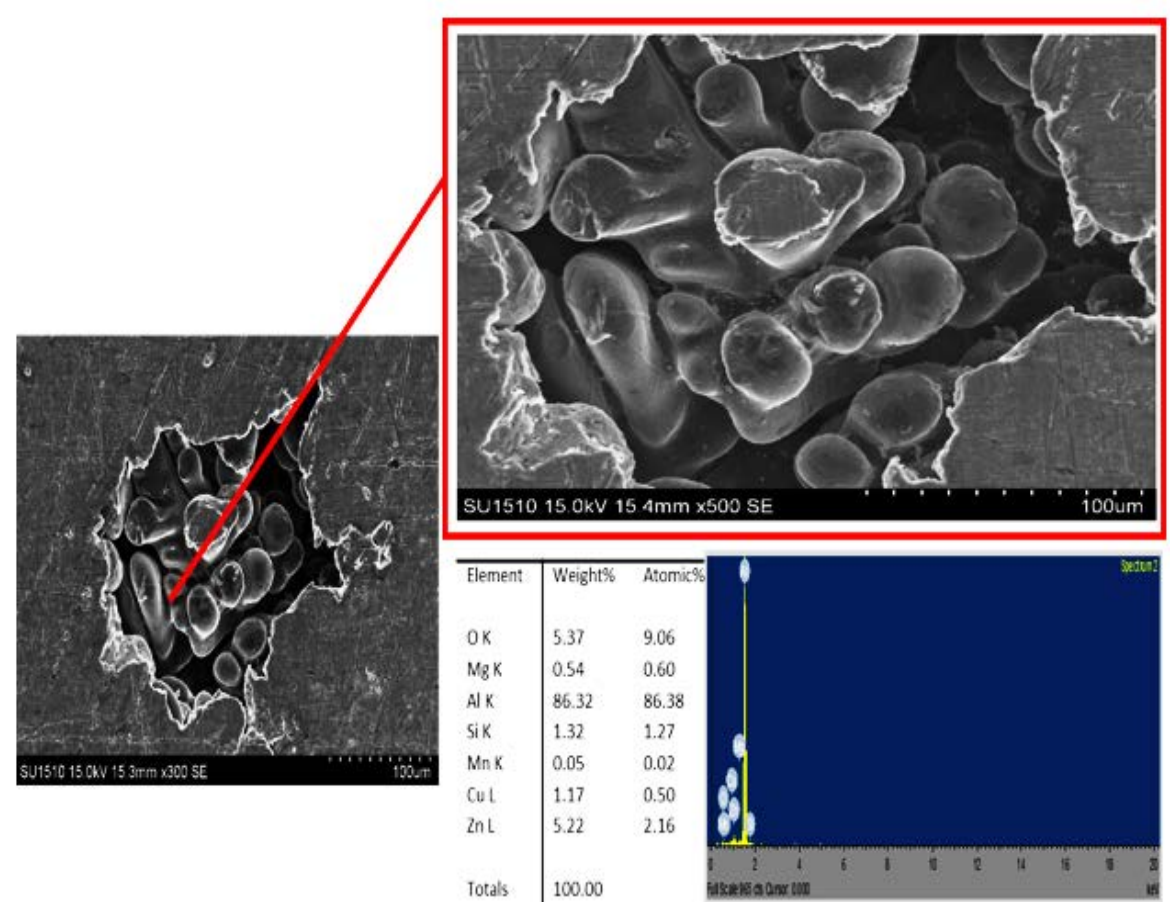

Figure 2. Dislocation/vacancy sites with typical elemental analysis 


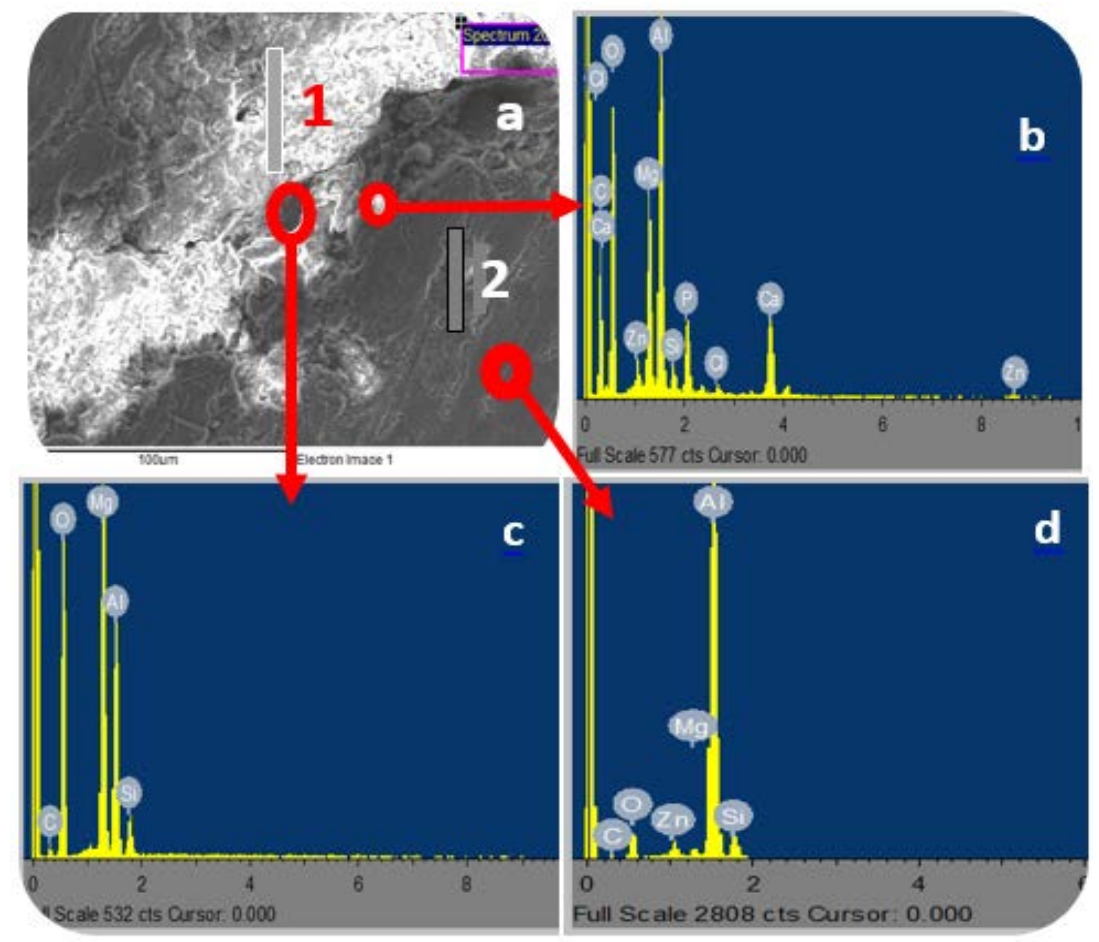

Figure 3. The 3 points' intergranular probe and elemental analysis of as cast alloy (a) morphology (b) - (d) elemental analyses

The first stage during solidification was characterized by free movement of liquid and solid mass. In figure 3a, point-1 was an interdendritic conglomeration supporting the formation of vacancies for precipitates [9]. The remaining liquid during solidification flowed through the dendritic network [3]. The results of elemental analysis (3b) support the formation of $\mathrm{Al}-\mathrm{Mg}_{2} \mathrm{Si}, \mathrm{AlMgZn}, \mathrm{Mg}_{32}$ (Al, $\mathrm{Zn})_{49}, \mathrm{MgZn}_{2}$ and $\mathrm{Mg}_{7} \mathrm{Zn}_{3}, \mathrm{MgZn}, \mathrm{Mg}_{2} \mathrm{Zn}_{3}$ and $\mathrm{Mg}_{2} \mathrm{Ca}$ [7]. The white phases were AlZnMgCu.

Amidst the AlZnMgCu phase was site C characterized by high Mg-Al-Si and oxide (void) that support the formation of $\mathrm{Mg}_{2} \mathrm{Si}, \mathrm{Mg}_{3} \mathrm{Si}_{2}$ and $\mathrm{AlMgSi}$ at about $448{ }^{\circ} \mathrm{C}$ [12].

For point 2, an AlZnMgSi phase with interdendritic supported the development of strength [3]. Phases like $\mathrm{CuMgAl} 2, \mathrm{Al}_{4} \mathrm{C}_{3}, \mathrm{Mg}_{5} \mathrm{Al}_{3}$ or $\mathrm{Mg}_{5} \mathrm{Al}_{8}$ were also reported in [13] in the presence of AlZnMgCu.

From the 17 points probe in figure 4, spectrum 1 was an $\mathrm{MgO}$ rich dislocation with $\mathrm{Al}_{3} \mathrm{Mg}_{47.90}$ phase. The highest $\mathrm{Mg}$ concentration observed was $47.90 \%$ which was higher than the $20.8 \%$ obtained by Schoenitz \& Dreizin [14]. The $49.10 \% \mathrm{O}$ was an indication of holes from $\mathrm{MgO}$ and material handling process. Phases like $\mathrm{Mg}_{3} \mathrm{Zn}_{3} \mathrm{Al}_{2}$ or $\mathrm{Mg}_{32}(\mathrm{Zn}, \mathrm{Al})_{49}$ were reported by Watanabe et al [15] when $\mathrm{Mg}$ was higher in the $\mathrm{Zn} / \mathrm{Mg}$ as in spectrum 1. The point contains a supersaturated solid solution of $\mathrm{Mg}$ in the $\gamma$-Al phase. The absence of $\mathrm{Zn}$ is peculiar to this spectrum. Spectrum 2 may support the formation of $\mathrm{Al}_{67.87} \mathrm{Zn}_{4.02} \mathrm{Mg}_{7.31}$ phase.

The presence of $\mathrm{Fe}$ (contamination) as apparently shown in spectrum 3, 10, 11, 13 and 15 may form possible phases such as $\mathrm{Al}_{85.86} \mathrm{Zn}_{5.32} \mathrm{Mg}_{1.01} \mathrm{Fe}_{1.78}$, $\mathrm{Al}_{85.41} \mathrm{Zn}_{4.81} \mathrm{Mg}_{1.09} \mathrm{Fe}_{1.65}, \quad \mathrm{Al}_{86.47} \mathrm{Zn}_{5.65} \mathrm{Fe}_{1.98}$, $\mathrm{Al}_{85.61}-\mathrm{Zn}_{4.78} \mathrm{Mg}_{0.86} \mathrm{Fe}_{1.87}$ and $\mathrm{Al}_{85.67} \mathrm{Zn}_{5.38} \mathrm{Mg}_{1.05} \mathrm{Fe}_{1.82}$ respectively. On the other hand, the lack of $\mathrm{Mg}$ was peculiar to spectrum 11 while Fe may be linked to the recycled aluminium used for the new material [16].

In all cases, the wt. \% of $\mathrm{Zn}(4.02-5.56)$ indicates that the X7475 was within the green letter specification and classified as a low Zn 7xxx alloy [17]. Elemental analyses of spectrum 14, 15 and 16 were pores-free sites. The three sites are 5.50, 5.38 and $4.63 \mathrm{wt} \% \mathrm{Zn}$ respectively. The wt. \% of $\mathrm{O}$ is lower in comparison to spectra 1 and 2, whereas the duo was at the middle of the pore.

Defects might manifest like extensive piping in contrast to distributed shrinkage porosity [18]. The cylindrical, bright interstitial and vacancy-like defect in Figure 5 is within the $\alpha-\mathrm{Al}$, dominated by C (contaminant) and $\mathrm{Zn}$. From the 8 spectra probe on the pipe, the core composed $64.90 \mathrm{C}, 37.04 \mathrm{O}, 0.52 \mathrm{Na}, 7.52 \mathrm{Al}$ (wt. \%). These defects may be typical of the material with the characterization of which the geometry is complex to be linked to the $\mathrm{H}$ of the material, but nonmetallic inclusions [18]. In figure 5, spectrum 1 was a site at the core of the pipe with a composition of 52.65 wt. \% C and 47.35 wt. \% O. The absence of $\mathrm{Al}, \mathrm{Zn}, \mathrm{Mg}$, and $\mathrm{Mn}$ signifies pores and inhomogeneity of the X7475. Spectrum 4 is a site on the pipe that has a composition of $55.21 \mathrm{C}, 31.05 \mathrm{O}$, and 12.64 Al. Similarly, spectrum 5 contains $52.30 \mathrm{C}, 26.17 \mathrm{O}$, $20.14 \mathrm{Al}$ and $1.39 \mathrm{Zn}$. The presence of $\mathrm{Zn}$ may be from the edge extending beyond the pipe. 


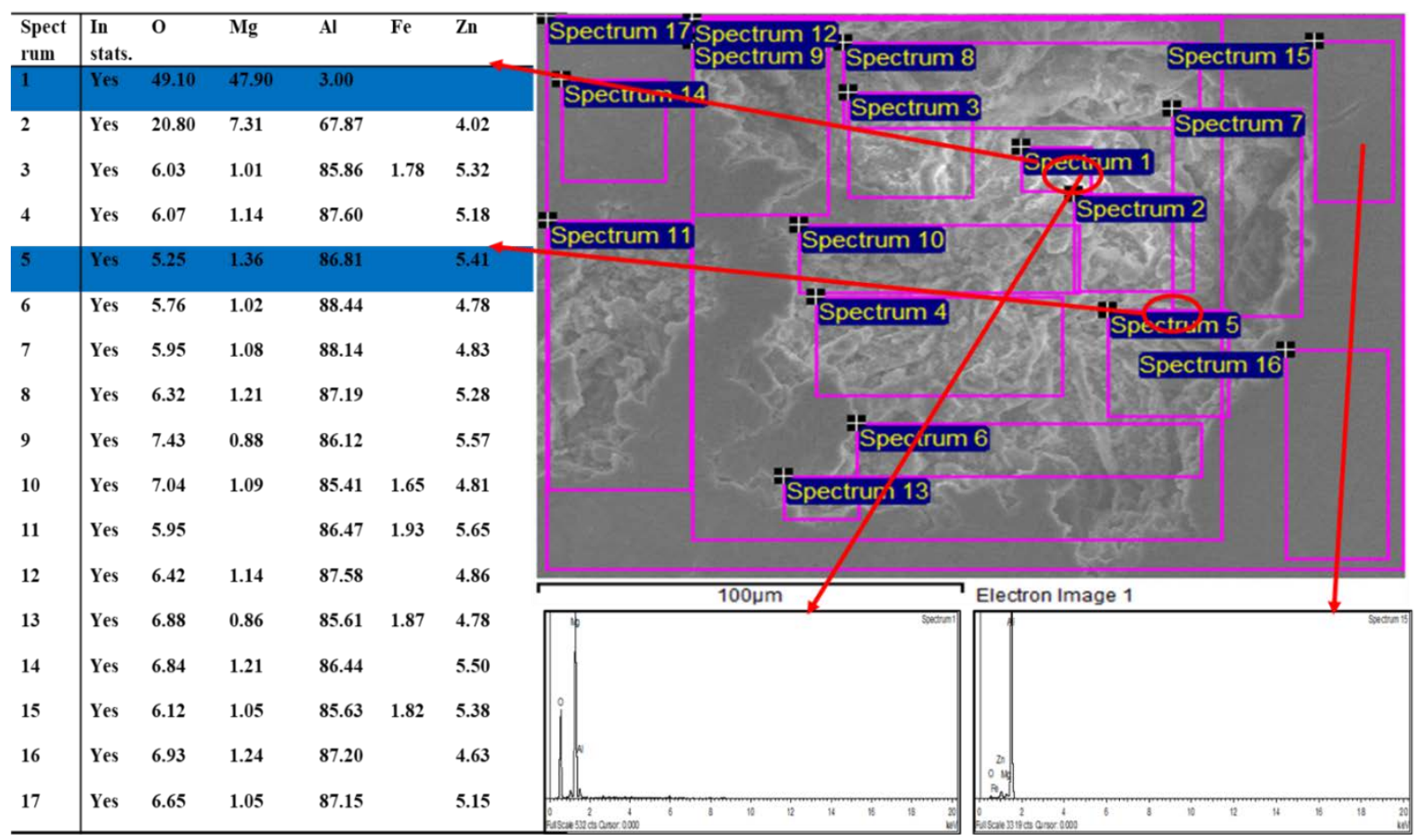

Figure 4. Elemental analysis in EDX 17-point probe of irregularities of artificially aged alloy

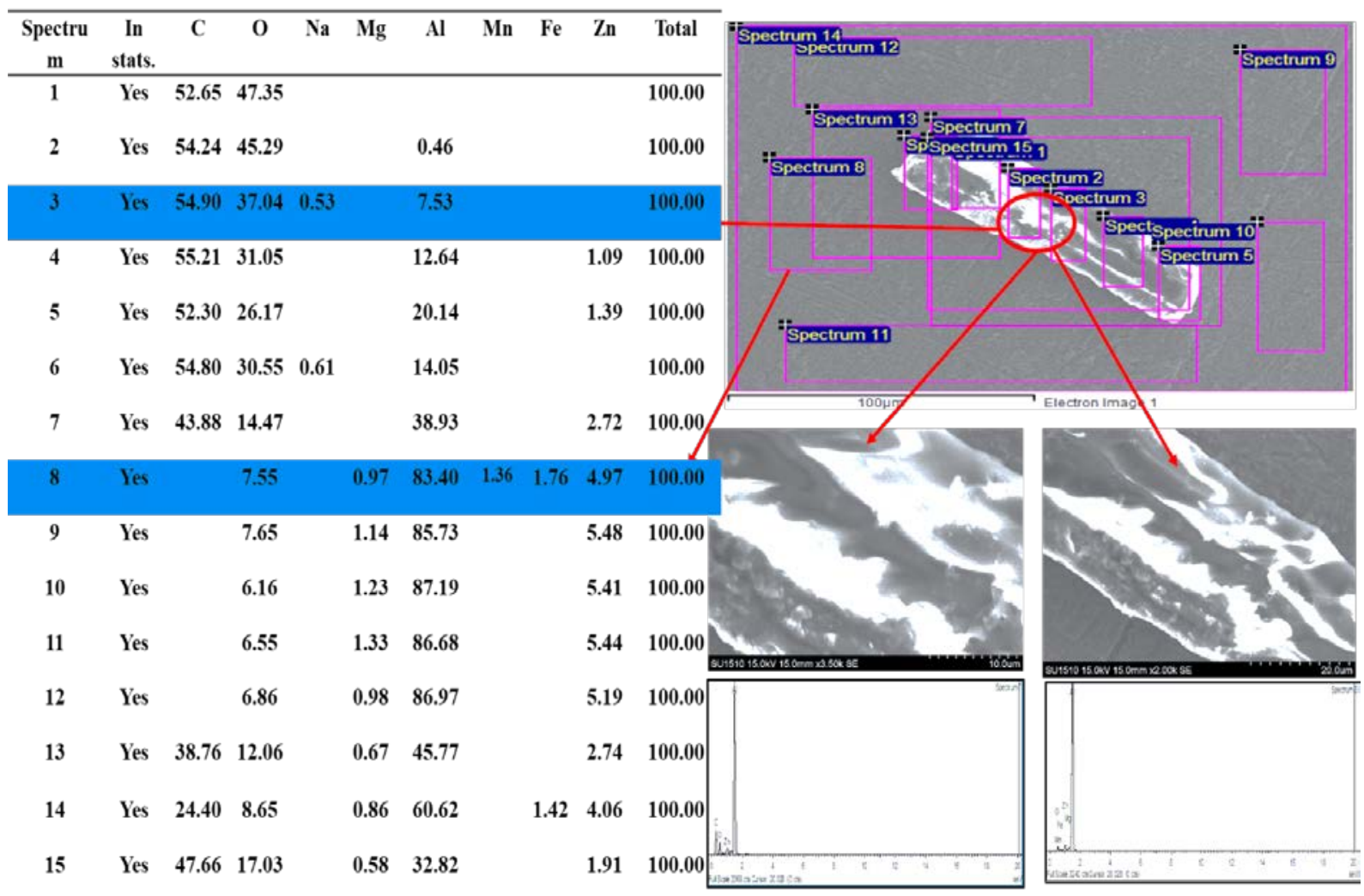

Figure 5. SEM image and elemental investigation of a polished X7475 alloy 500x, 3500x and 4000x 
Spectrum 6 consists of $54.80 \mathrm{C}, 30.55 \mathrm{O}, 0.61 \mathrm{Na}$ and $14.04 \mathrm{Al}$. $\mathrm{Na}$ as an impurity might be picked from secondary aluminium. Spectrum 7 has $43.88 \mathrm{C}, 14.47 \mathrm{O}$, $38.93 \mathrm{Al}, 2.72 \mathrm{Zn}$. $\alpha$-Al phase that was observed within the pores. Spectrum 8 was outside the pore and contains $7.55 \mathrm{O}$, $0.97 \mathrm{Mg}, 83.40 \mathrm{Al}, 1.36 \mathrm{Mn}, 1.76 \mathrm{Fe}$ and $4.97 \mathrm{Zn}$. However, the presence and any increase in $\mathrm{Mn}$ and Fe may increase the Chinese script morphology, intermetallic $\mathrm{Al}_{6}(\mathrm{Fe}, \mathrm{Mn})$. This phase may be favourable to the mechanical property. Rate of cooling is important in the formation and refinement of intermetallic Liu et al [19]. Spots 9 to 12 were $\mathrm{C}, \mathrm{Na}, \mathrm{Mn}$ and $\mathrm{Fe}$ free, with wt. \% of $\mathrm{O}, \mathrm{Mg}, \mathrm{Al}$ and $\mathrm{Zn}$ ranging from 7.65-6.16, 1.33-0.98, 87.19-85.73 and 5.48-5.19 respectively.

Spectrums 13-15 are flicking through both the entire and specific points of the sample and consist of $\mathrm{C}, \mathrm{O}, \mathrm{Mg}, \mathrm{Al}$ and $\mathrm{Zn}$. The main phases in 7xxx alloys were $\alpha-\mathrm{Al}$ and $\mathrm{MgZn}_{2}$. Spectrum 14 was an exception with $1.42 \mathrm{Fe}$ as impurity. $\mathrm{Al}_{0.5} \mathrm{Fe}_{3} \mathrm{Si}_{0.5}$ was phases within this spectrum. The $\mathrm{MgZn}_{2}$ and $\alpha-\mathrm{Al}$ were feasible phases in the presence of $0.86 \mathrm{Mg}, 4.06 \mathrm{Zn}$ and $60.62 \mathrm{Al}$.

Morphological characterizations and $\mathrm{H}$ (mechanical property) were products of alloy constituents, solidification conditions and HTs. The result of MH in Figure 6 saw an alloy of $5.0 \mathrm{wt}$ \% $\mathrm{Zn}$ and artificially aged (T6) having obtainable peak $\mathrm{H}$ of $139.23 \mathrm{Hv}$. The formation of hardening phases like the $\mathrm{MgZn}_{2}$ precipitates may inform the increases in $\mathrm{H}[20]$. T4 recorded $134.32 \mathrm{Hv}$ whereas, the O, the same alloy had $89.11 \mathrm{Hv}$. The wt. \% of Zn and HT influenced $\mathrm{H}$.

With decrease in wt. \% $\mathrm{Zn}$ from 5.0 to 4.5, obtainable $\mathrm{H}$ at T6 was $104.46 \mathrm{Hv}$. T4 recorded a higher $\mathrm{H}$ of $128.82 \mathrm{Hv}$ and a least of $73.38 \mathrm{Hv}$ in $\mathrm{O}$ alloy. On the contrary, a further decrease to $4.0 \mathrm{wt}$. \% resulted in $140.45 \mathrm{Hv}$ in the T6 condition. The same alloy had an obtainable $\mathrm{H}$ of $121.09 \mathrm{Hv}$ and $74.25 \mathrm{Hv}$ in the T4 and O conditions. This was a reflection of the complexity of $\mathrm{H}$ and the relevance of correlating $\mathrm{H}$ with other mechanical property.

Defect arrangement, size, intermetallic phase dispersal are morphological characteristics that strongly affect mechanical properties. Other microstructural considerations are the dendrite arm spacing, grain boundary, size and shape. Inclusions in the conditions are the eutectic modification and primary phase refinement which may be altered through HTs [19].

Increase in $\mathrm{Mg}$ may result in decrease in $\mathrm{H}$. These categories of alloys had the least $\mathrm{H}$ as shown in Figure 6. An alloy of 1.75 wt. \% Mg had an obtainable $\mathrm{H}$ of $72.05 \mathrm{Hv}$ in $\mathrm{T} 6$ condition and $87.05 \mathrm{Hv}$ in $\mathrm{O}$ conditions respectively. With decrease in wt. \% $\mathrm{Mg}$ from 2.0 to 1.5 , a corresponding decrease in $\mathrm{H}$ was observed with $71.85 \mathrm{Hv}$ (T6), $66.78 \mathrm{Hv}$ (T4) and 63.80 (O). An alloy of 1.25 wt. \% $\mathrm{Mg}$ recorded a higher $\mathrm{H}$ in comparative to the $1.50 \mathrm{wt}$ \% $\mathrm{Mg}$. A peak $\mathrm{H}$ of $82.74 \mathrm{Hv}$ was observed in the $\mathrm{O}$ condition, whereas $75.26 \mathrm{Hv}$ and $73.79 \mathrm{Hv}$ were recorded in T6 and T4. This result may be linked to the defects and pores as observed in the coupons before and after HT.

When $\mathrm{Zn}$ and $\mathrm{Mg}$ were held at 5 wt. \% and 1.75 wt. \% $\mathrm{Mg}$ and Mn varied, a maximum obtainable $\mathrm{H}$ of $120.44 \mathrm{Hv}$ was recorded at T6 when Mn was 0.075 wt. \%. $\mathrm{H}$ was seen to reduce to $74.68 \mathrm{Hv}$ in the T4 condition and $62.96 \mathrm{Hv}$ in $\mathrm{O}$ condition. The $\mathrm{H}$ when 0.05 wt. \% $\mathrm{Mn}$ was used in the alloy was $76.85 \mathrm{Hv}$ (T6), $69.60 \mathrm{Hv}(\mathrm{O})$ and $82.53 \mathrm{Hv}$ (T4). The result was better in all the conditions with decrease in Mn to 0.025 wt. \%. H values were 100.18 (T6), $80.17 \mathrm{Hv}$ (T4) and $52.18 \mathrm{Hv}(\mathrm{O})$ respectively. 


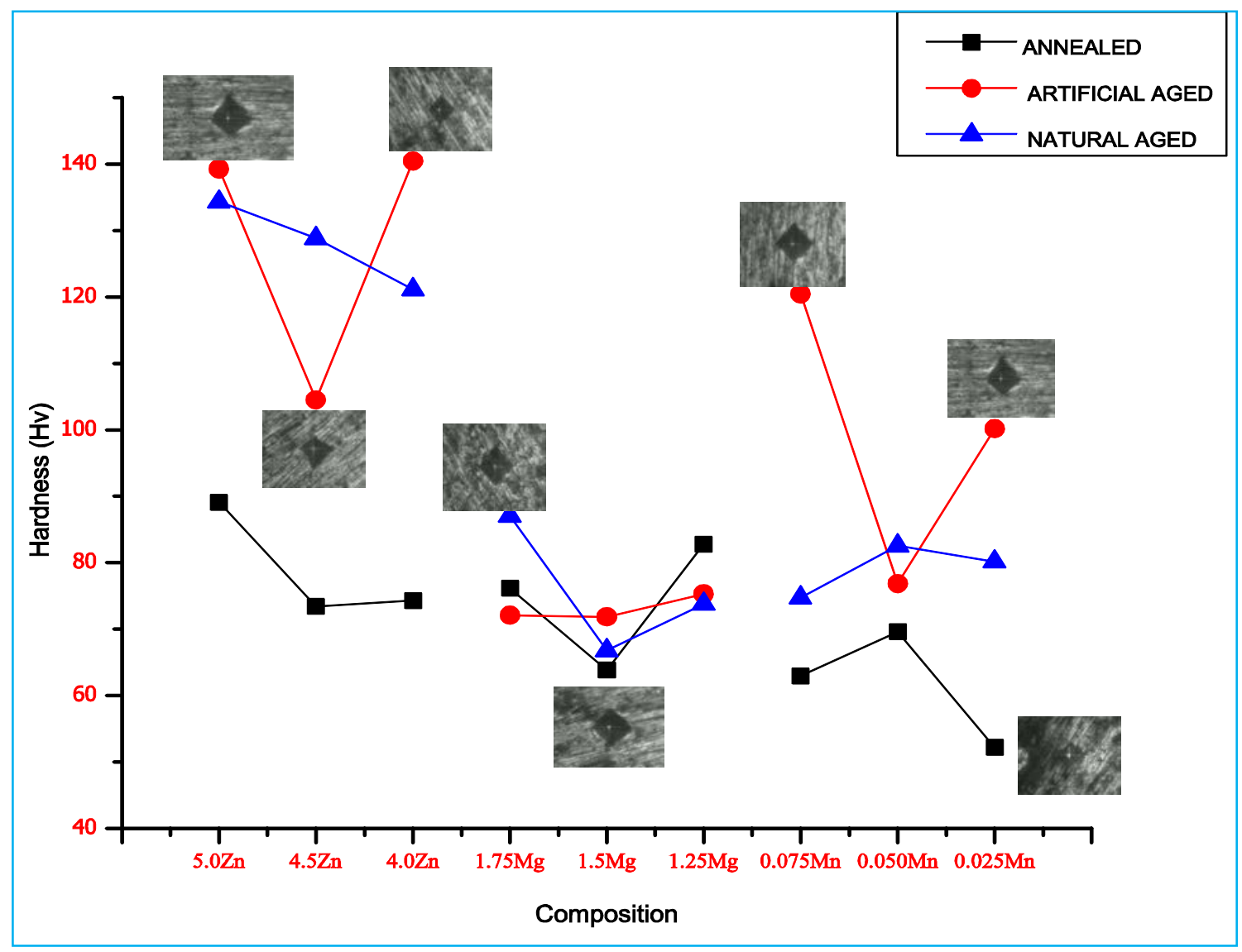

Figure 6. Microhardness and composition of X 7475 alloys

\section{Conclusions}

Materials composition, HT, materials handling, dispersal of hardening precipitates and casting process were among key factors that affected the morphological, microstructure and mechanical properties of the new X7475 alloy produced. Pores and inhomoginized characterization were observed. Formation of hardening phases was possible with the elemental analysis observed. A peak $\mathrm{H}$ of $140.45 \mathrm{Hv}$ was obtained in an alloy of $4.5 \mathrm{wt}$. \% $\mathrm{Zn}$ at T6 and least of $52.18 \mathrm{Hv}$ in an alloy of $0.025 \mathrm{wt}$ \% \% $\mathrm{Mn}$. The result and characterization reflected the effect of defects in X7475 alloy produced from RBC. Future studies may focus on correlating the $\mathrm{H}$ with conductivity and physical properties of the alloy. Optimization of the mechanical properties vis-à-vis the HT process is germane to obtain a better microstructure and morphology.

\section{Acknowledgements}

We acknowledge the Center for Graduate Studies (CGS), Universiti Tun Hussein Onn Malaysia for supporting this publication. National Centre for Technology Management (NACETEM), North Central Office, FCT-Abuja, Nigeria in the area of research collaboration and support. We appreciate the assistance of
Mr. Mohd. Tamizi Nasir and Mr. Annuar Ismail of Materials Laboratory UTHM.

\section{REFERENCES}

[1] A. John and N. M.B, "Modelling and Analysis of an Automotive Bumper Used for a Low Passenger Vehicle," Int. J. Eng. Trends Technol., vol. 15, no. 7, pp. 344-353, 2014.

[2] N. Tanlak, "Shape optimization of beams under transverse crash,” no. June 2012, 2012.

[3] D. G. Eskin, Suyitno, and L. Katgerman, "Mechanical properties in the semi-solid state and hot tearing of aluminium alloys,” Prog. Mater. Sci., vol. 49, no. 5, pp. 629-711, 2004.

[4] S. L. George and R. D. Knutsen, "Solidification of an Al-Zn alloy during semi-solid processing,” J. South. African Inst. Min. Metall., vol. 111, no. 3, pp. 183-186, 2011.

[5] J. Jiang, Y. Wang, and H. V. Atkinson, "Microstructural coarsening of 7005 aluminum alloy semisolid billets with high solid fraction,” Mater. Charact., vol. 90, pp. 52-61, 2014.

[6] S. J. Andersen, C. D. Marioara, J. Friis, and S. Wenner, "Advances in Physics: X Precipitates in aluminium alloys," 
Adv. Phys. X, vol. 3, no. 1, 2018.

[7] Z. Hu, L. Wan, S. Lü, P. Zhu, and S. Wu, "Research on the microstructure, fatigue and corrosion behavior of permanent mold and die cast aluminum alloy,” Mater. Des., vol. 55, pp. 353-360, 2014.

[8] M. N. Mohammed, M. Z. Omar, M. S. Salleh, K. S. Alhawari, and P. Kapranos, "Semisolid metal processing techniques for nondendritic feedstock production," Sci. World J., vol. 2013, no. September, 2013.

[9] O. O. Ajibola, D. T. Oloruntoba, and B. O. Adewuyi, "Metallurgical study of cast aluminium alloy used in hydraulic brake calliper,” Int. J. Innov. Sci. Res. ISSN, vol. 8, no. 2, pp. 2351-8014, 2014.

[10] R. Vissers, "The crystal structure of the phase in $\mathrm{Al}-\mathrm{Mg}-$ Si alloys,” vol. 55, pp. 3815-3823, 2007.

[11] M. P. Agustianingrum, N. A. Arandana, R. Wijanarko, and B. T. Sofyan, "Effect of deformation and annealing temperature on the mechanical fabricated by squeeze casting," MATEC Web Conf. 153, 01001 ICMME 2017, vol. 01001, pp. 5-10, 2018.

[12] M. Schoenitz and E. L. Dreizin, "Structure and properties of Al - Mg mechanical alloys,” vol. 07102, no. May, pp. 1827-1836, 2003.

[13] K. Watanabe, K. Matsuda, S. Ikeno, T. Yoshida, and S. Murakami, "TEM observation of precipitate structures in Al-Zn-Mg alloys with additions of $\mathrm{Cu} / \mathrm{Ag}$,” Arch. Metall. Mater., vol. 60, no. 2A, pp. 977-979, 2015.

[14] J. Gilbert Kaufman Elwin L. Rooy, Aluminum Alloy Castings: Properties, Processes, and Applications, vol. 14, no. 1. 2018.

[15] “Alcoa Specialty Alloys : EverCast TM,” 2015.

[16] The Aluminium Association, "International Alloy Designations and Chemical Composition Limits for Wrought Aluminum and Wrought Aluminum Alloys with Support for On-line Access from: Aluminum Extruders Council Use of the Information,” no. January, 2015.

[17] Y. Liu, G. Huang, Y. Sun, L. Zhang, Z. Huang, and J. Wang, "Effect of Mn and Fe on the Formation of Fe- and," vol. 6, 2016.

[18] L. Li et al., "Effect of Zn Concentration on the Microstructure and Mechanical Properties of Al-Mg-Si-Zn Alloys Processed by Gravity Die Casting,” Metall. Mater. Trans. A, vol. 49, no. 8, pp. 3247-3256, 2018.

[19] Z. Wei-chao, L. I. Shuang-shou, T. Bin, and Z. Da-ben, "Microstructure and properties of Mg-Al binary alloys," pp. 270-274, 2006. 